\title{
Historical Cupping Therapy of the Resettled Czech Community from Ukraine in the Context of Contemporary and Alternative Medicine in the Czech Republic ${ }^{1}$
}

\begin{abstract}
Cupping therapy is an ancient technique of healing used for a whole spectrum of health problems in a wide range of ways, variations and methods. Besides the type of material used, the forms of application and explanation of the mechanism of the effect, the methods of its conduct differ. In addition to medical grasp of the subject, a broader and more comprehensive view of this method is also supported by a comparison of the historical variations and forms across territorial units and time horizon. For this purpose, both the historical context of cupping therapy on the territory of the Czech Republic, its archaic form captured within the community living in emigration in Ukraine and a brief overview of the current situation in the Czech Republic are depicted. The data was collected in 2008-2018 within three waves of resettled Czechs from Ukraine all over the territory of the Czech Republic.
\end{abstract}

Keywords: Volhynia Czechs, folk medicine, cupping therapy, migration, Czech Republic, Ukraine

This study was written with the institutional support of the Institute of Ethnology of the Czech Academy of Sciences, v.v.i., RVO: 68378076. 


\section{Introduction}

The article discusses the community of Czechs resettled from Ukraine back to the Czech Republic (CR) and their treatment strategies, with particular attention to the therapy with cups. The ancestors of the resettled Czechs set out in the second half of the $19^{\text {th }}$ century, in accord with the geopolitical settings of the time and as an antipole of the Western migration tendency, from then Austro-Hungary to the east to colonize the territory of tsarist Russia in return for the promise of a better livelihood. They left a culturally different milieu for a then agriculturally underdeveloped and culturally poorer areas of Tzarist Russia at the time, which resulted in the preservation of many imported customs, traditions and handicrafts methods. This applies not only to cultural and agricultural areas, but also to the treatment of disease and maintenance of health. Their collected memories are currently a unique preserved testimony of the archaic methods used not only in Central Europe itself (then Austro-Hungary) of the $2^{\text {nd }}$ half of the $19^{\text {th }}$ century, but also their subsequent transformation in the Ukrainian milieu in the $19^{\text {th }}$ and $20^{\text {th }}$ centuries with an overlap to today. This text aims to illustrate the ancient form of cupping therapy of this unique group of Czechs in Ukraine, now resettled in the Czech Republic, and describe a current cupping therapy in the context of complementary and alternative medicine (CAM) in the Czech Republic.

\section{Czechs in Ukraine and Their Resettlement to the Czech Republic}

The observed group of migrating people from the Czech lands of then AustriaHungary (now the CR) set out on the journey at the time when the empire of the monarchy was disrupted by internal disputes and wars with neighbouring states. In the Czech lands, people began to live poorly after the lost war with then Prussia (now Poland and Germany) in 1866. There was a lack of arable land, job opportunities; people were in need of a decent living. It resulted in internal and external migration. Internal migration lay in relocation within then Austrian monarchy, when the populace was most attracted by Vienna (the residential city of the Habsburg monarchy) and the southeast parts of the empire (the Balkans). Beyond the borders of Austria-Hungary, emigration to the United States was very popular at the time, whereby, from 1862 onwards, the so-called Homestead Act yielded federal farmland free of charge, and shipping became cheaper, contributing to greater mobility. Nevertheless, ship transport remained the significant obstacle, and many people from the middle and lower classes preferred to travel to other destinations overland. Part of the migrating populace hence set out eastwards. In tsarist Russia, which shared its western border with Austria-Hungary, the re- 
formist-thinking Tsar Alexander II ruled from 1855, who endeavoured for a modernization of the large empire and thus opened the doors to those coming with an offer of land and many other advantages and benefits.

In response to the call to come settle, Czechs, considered by their Eastern neighbours as a related Slavic population (Slavs) capable of integration into Russian society, began to flow into the southern and especially southwestern border and strategically important areas of tsarist Russia - the Volhynia and later also the Kiev Gubernia from the 1860s. The emigrants who settled in the Volhynia region were predominantly from Central and East Bohemia, fewer of them came from South Bohemia and Moravia (Valášková, Uherek, Brouček 1997). In Ukraine they founded several new villages or were settled in villages and small towns alongside the original Ukrainian population. This, however, did not stop the movement between the two countries or across them either, people continued to migrate even from Volhynia, partially to the aforementioned America, partly to other parts of Europe. Reason for this subsequent migration was the gradual deterioration of living conditions in Ukraine, and the deepening of family and business networks. So, even a part of the community of Volhynian Czechs went back into motion and migrated back to the territory under the large Austrian monarchy after the death of Alexander II in 1881. After the implementation of the assimilation policy of Alexander III - for example, it founded three colonization communities in Bosnia and Herzegovina (Uherek 2011).

Before WWI, something around 30000 Czechs lived in Ukraine's Volhynia in 174 communities, after WWII approximately 40000 Czechs were counted in 634 communities (of that 110 were purely Czech, 158 mixed communities, in 366 communities the Czech compatriots lived in the minority) (SČVP). These Czech compatriots after the experiences of the bloody conflicts of WWI when Volhynia was occupied by the Austro-Hungarian and German Armies along with fighting Red Army striving to create an independent Ukraine separate from Russia, the subsequent Bolshevik Revolution, Soviet persecution, violence committed during WWII by the Nazis and Ukrainian nationalists decided at the end of WWII to return to the land of their ancestors (now the Czech Republic) and gradually came in the three following waves:

1) Czechs from Volhynia and their descendants (state-controlled re-emigration in 1945-1948, ca almost 40,000 inhabitants) (Valášková, Uherek, Brouček 1997: 25-28).

2) Czechs from Kiev and Zhytomyr regions after the Chernobyl accident (humanitarian resettlement program 1991-1993, approx. 1,700 inhabitants) (Valášková, Uherek, Brouček 1997: 35-49).

3) Czechs - modern re-emigrants from the southern and eastern parts of Ukraine as a result of the war (coming from 2014, about 1000 inhabitants). 
At present, the estimates of Czechs who stayed in Ukraine and did not take part in resettlement events at the original settlement sites are approximately 5000 people, mostly mixed married couples and older family members (MZV ČR).

\section{Conceptual Framework of Medical Anthropology}

Medical anthropology (MA) is an indispensable and necessary conceptual framework wherever we strive to understand aspects of human living related to health, disease and their treatment in their own and social environment and relation to the surrounding world (Kleinman 1980). Thus, it becomes a suitable conceptual framework for our understanding of cupping therapy as one of many forms of folk treatment. MA began as a scientific discipline developed at the end of World War II, at a time of enormous losses of life, human suffering and the progress of medical approaches. The conceptual development of MA occurred mainly in the 1960s when The Society for Medical Anthropology was founded in 1967. George Foster and Barbara Anderson have been principal pioneers in the United States, who have directed human health research to investigate not only biological but also socio-cultural factors affecting the incidence of diseases in varied contexts (Foster, Anderson 1978). At the same time, the MA in the Netherlands began to develop due to the productive activities of missionaries and medical workers in developing countries in the former Dutch colonies (Geest 2007). In order to understand the importance of the cupping practice in the then Czech community in Ukraine, it is appropriate to focus on the specific branch of the MA, namely the critical medical anthropology (CMA), which began to develop in the 1970s and 1980s. CMA focused its attention on the socio-cultural spheres of medicine in the complex western society, taking into account, in addition, the middle level of social organization and the macro-level of social structure (Ember, Ember 2004). This is especially necessary in the case of difficult life in turbulent conditions of political and socio-economic settings in the area of the former USSR in the then Czech community in Ukraine to be taken into account.

\section{Chinese Medicine in the Context of Complementary and Alternative Medicine (CAM) in the Czech Republic}

The study of various types, practices and functions of complementary and alternative medicine (CAM) is one of the central themes of both MA and CMA. Let us now look at how Chinese medicine, of which cupping therapy is a crucial part, is anchored in the context of CAM in the Czech Republic and, on its example, to describe the development of CAM in the Czech Republic. 
Cupping therapy had emerged as the healing method of traditional Chinese medicine along with the bloodletting method in the Czech Lands since the early $16^{\text {th }}$ century, when it was found in both the monastic environment and at home, and then carried out by local barbers, spa servants, healers, or physicians (Choceňský 1532). Cupping therapy as a component of bloodletting was used relatively abundantly on the territory of the Czech lands. Whereas in the works from the $16^{\text {th }}$ century, cupping therapy is recognized within the methods of bloodletting, in the medical treatises from the end of the $19^{\text {th }}$ century it is already presented as uncommon and already only seldom used (Choceňský 1532; Pavlík 1897). Over time and with the development of education, cupping therapy gradually gave way to the grey zone in the Czech Republic, where medical science never recognized folk medicine and CAM. These two areas began to grow rapidly in the aftermath of the change in the political regime in $1989^{2}$. The Chinese Medicine (CM) also experienced an enormous boom - in the 1990s the $1^{\text {st }}$ School of Traditional Chinese Medicine (TCM) was founded in the capital. However, this situation, along with insufficient awareness and chaotic anchoring in the healthcare system, often led to the flourishing of fraudsters and so-called health merchants. It was and still is to a certain extent likely also because of the insufficient and unclear conceptual terminology, when the issue of unconventional medicine can be likened to another of the "problematic" disciplines in the Czech Republic - psychosomatics, which has, however, been doing much better over the past few years thanks to several small top-notch people in scientific circles (Křižzová 2013). CAM has not yet found a way in the Czech Republic into the system of state-covered medical insurance (except for the brief considerations of the Czech system regarding Chinese medicine) or into the surgeries of Czech physicians and only to a small degree is it tolerated or directly recommended by physicians for patients. There is no general CAM legislation, no professorial chair for CAM, nor regulations regarding supervision of CAM practitioners in the Czech Republic (CAM Regulation 2013).

This is also the case of traditional Chinese medicine, with which the situation has improved for a short time on the territory of the Czech Republic in 2015. In Hradec Králové, a surgery of Chinese medicine was opened at the University Hospital with a view to building an entire clinic, which was to become a private Chinese company called CEFC China Energy. At the beginning of 2019, however, a report ran through the media on the closure of the outpatient area and the withdrawal of Chinese investors from plans to build a clinic (Kenety 2019; Taneček 2019). The Chinese specialists, who mainly applied acupuncture to the patients - self-paying customers, to this day are not legally enshrined in the legislative system of the Czech Republic and the route to that is likely not in sight, just like with

2 Before 1989 the Communist regime dominated the then Czechoslovakia from 1948 and survived until the fall of the Iron Curtain in 1989 (Vaněk, Mücke 2016; Leff 2018). At that time, folk healing was considered backward and was persecuted by state authorities. 
the prepared discussion of an act on healing, where it is mainly for the moment about introducing a register, acquiring authorisation to provide healing services and compulsory liability insurance at the expense of proving knowledge, abilities and skills (iDNES 2018; Cikrt 2019). The current state of the legislation (when Chinese medicine is not counted among the healthcare fields) thus does not allow the continuation of the activity or a Chinese specialist in the affiliated medical surgery of Chinese medicine at the University Hospital in Hradec Králové. The activity of Chinese medicine encountered great interest of the patients here (over three years, nearly three thousand patients looking for help with predominantly chronic pain went through the surgery), but with great opposition from the medical scientific community, which pushed for the final withdrawal of Chinese medicine from the list of regular medical disciplines and inclusion among healing services alongside homeopathy, practicing reiki or psychotronics. The international cooperation with the Shanghai's University Hospital Shuguang at the University of Shanghai thus remained only at the endowment fund level, but it only functions as a counselling centre, not a provider of treatment care.

Probably as a result of not being enshrined in the legislative framework of the Czech Republic and thus given vague definition of all the interested parties resolving healthcare problems with the methods of Chinese medicine, a competition battle and conflicts emerged between the three streams of the practice of Chinese medicine, which gradually appeared on the territory of the Czech Republic in the course of the political, economic and social changes. First and foremost, it was medical acupuncture institutionalized in communist Czechoslovakia (before 1989) as a specialization within biomedical healthcare, second, dissident Chinese medicine practiced in the framework of bilateral exchanges of students and staff of friendly countries of the former Soviet bloc with a different epistemological framework of the theory of health and disease (individual representatives of this practice institutionalized themselves as private schools and clinics after the political change in 1989, but are marginalized by the biomedical establishment), and last but not least, the aforementioned state-sponsored version of Chinese Medicine, which has become a power tool of political influence and support after 2013 for the revival of economic and political cooperation between the Czech Republic and China (Stöckelová, Klepal 2018).

Thus, for the time being with no functioning legislative basis, patients are reliant on their own judgment and self-study of the issue in the area of practicing Chinese medicine, but de facto the entire CAM field, since there is no register or relevant education system or evaluation system for trainees of CAM in contrast to neighbouring countries. Despite this, the majority of the Czech population leans towards CAM and the number of accessible alternative methods is continually increasing (Halasová 2006). According to some experts in the Czech Republic, CAM does not compete with so-called evidence-based medicine, but it exists to fill a space that scientific medicine leaves unoccupied, be it the area of long-term 
chronic problems or psychosomatic problems directly related to the way of life, mental attitudes and relationships (Kř́žzova 2018). Nevertheless, the officially recognized scientific medicine as a cultural dominant sphere in the field of medical care in the Czech Republic has the need to devalue and marginalize the minority position of so-called alternative options due to possible health risks caused by rogue practitioners and is trying to monopolize the health and disease discourse for the benefit of university-educated medical professions. However, despite many warnings or dissuasive cases, according to empirical research on the use of unconventional treatment methods in the event of health problems, the population is looking at the whole issue with different optics.

The overall level of experience with the five monitored alternative directions (acupuncture, homeopathy, herbal treatment, therapeutic diet and healing) reached 68\% in 2011 and in 2014 already 76\% (Křížová 2001; Pokladnikova, Selke-Krulichova 2016, 2018). The most widely used procedures include phytotherapy (Knotek et al. 2012), vitamins/minerals supplements, massage, relaxation and various dietary supplements. The growth is clear in recent years particularly with drinking herbal teas - 48\% (2011) versus 53\% (2014), massage practices $20 \%$ (2011) versus 26\% (2014), relaxation methods - 10\% (2011) versus $19 \%$ (2014) and practicing yoga - 3.7\% (2011) versus 7.1\% (2014) (Pokladnikova, Selke-Krulichova 2018). The directions of CAM are generally sought by people thanks to the methods that understand the person holistically. Many thus perceive contemporary Czech medicine (despite, and thanks to its technological advancement and high level) more as a medicine of diseases than a medicine of the person (Škoda 2002), which does not necessarily have to be harmful. Thanks to the advanced technological aspects of Czech medicine and the economic background of the Czech population, CAM can boast an area for which it can serve very well without seriously hurting anyone and without competing with the hegemonic Western scientific so-called evidence-based medicine, and that is the area of prevention, or convalescence. From the recent research, it came to light that prevention was the primary reason for CAM use (82\%) and only $15.9 \%$ of CAM users employed it for therapeutic purposes (Pokladnikova, Selke-Krulichova 2016). Thus, whereas in economically less developed countries folk medicine and CAM often serve as the only or an affordable form of medical assistance and healthcare service, the opposite situation occurs in the Czech Republic. Thanks to the set system of health and social insurance, CAM can be used as a paid complementary or alternative supplement to the standard state-funded health care. Alternatively, the inhabitants of the CR use CAM in lighter cases, most often respiratory (35\%), musculoskeletal $(33,6 \%)$ or gastrointestinal problems, which do not require medical treatment (Pokladnikova, Selke-Krulichova 2016).

In general, half of the population of the Czech Republic combines CAM with conventional medical treatment, i.e. it tends towards the concept of complementary rather than alternative medical care. The community of the resettled Czechs 
from Ukraine, which on the site of its activity in Ukraine utilised the methods of CAM and the wisdom of folk medicine handed down from generation to generation to a much greater extent, tends towards the discovered results because of the inaccessibility and high financial burden of state-provided healthcare than here in the CR, where they tend rather towards the official standard of Western medicine. However, they still maintain some methods, whether in the living memory or directly in practice (mainly phytotherapy, to a small extent cupping therapy and hirudotherapy).

\section{Cupping Therapy in the Czech Republic}

Like the other directions of CAM, cupping therapy is built on a holistic and dynamic understanding of the interactions and relationships of body, mind and surroundings and just like the majority of similar directions, often of a similar age, this method was almost forgotten in the Czech Republic in the $2^{\text {nd }}$ half of the $20^{\text {th }}$ century as was the case in other economically similarly developed countries. The history of its use reaches deep into the third millennium $\mathrm{BC}$ on the territory of Mesopotamia, Egypt and later Greece, where the cup was part of the logo of a physician. Cupping therapy received its greatest fame in China, from which this practice comes and where it is applied as an integral part of the traditional system of healing, which since the 1950s has been given joint research with the acupuncturists from the former Soviet Union and was subsequently established as an official therapeutic practice in hospitals all over China (Cao et al. 2010). Cupping therapy was an integral part of many ancient treatment systems, mentions of which are also found in traditional Korean, Tibetan and Oriental medicine (Qureshi et al. 2017). As a result of the fall of the Roman Empire at the end of the $4^{\text {th }}$ century AD and the subsequent ethnic changes, this practice almost died out in Europe, only to return to Europe again in the $9^{\text {th }}$ century through the Arabian Peninsula. From the $14^{\text {th }}$ to $17^{\text {th }}$ centuries, cupping therapy expanded from Renaissance Italy all over Europe and at the dawn of the $20^{\text {th }}$ century using that method had already become the domain of folk medicine and home self-healing (Abele 2006; Aboushanab, AlSanad 2018). The popularity of cupping therapy was commensurate with that of acupuncture, which also began to spread through trade contacts already in the $6^{\text {th }}$ century, and, along with knowledge of other Chinese healing methods, penetrated Europe with missionaries and members of the East India Company (Piotrowski-Manz 2007).

The modern development of cupping therapy in the Czech Republic is related to the change of the political setting and transition from a totalitarian regime to a parliamentary democracy after 1989 (Vaněk, Mücke 2016; Leff 2018). Many different directions and variations of cupping methods are found on the territory of the Czech Republic, most often carried out by glass cups of different sizes $(25-90 \mathrm{~mm})$ 
or cup made of plastic with a suction rubber balloon or suction valve. In the first case, a vacuum is created in the cup by rapidly inserting and removing a burning cotton bud and then sucking the cup to the skin. In the latter case, the vacuum can be continuously adjusted by means of a suction valve or a rubber balloon. It is also possible to encounter on the territory of the Czech Republic porcelain, silicon, imported bamboo cups or those made from various materials, often of a curious nature, which however do not serve for healing practices but rather as cultural artefacts. In the past, wooden or brass cups were also used (Zíbrt 1924).

Most commonly, the method of dry cupping/retained cupping is currently used on the territory of the Czech Republic, which is most frequently utilized for treating the hardened places mainly on the back that happens as a result of insufficient blood supply, exertion, stress and insufficient supply of the cells with oxygen. Most often, glass or plastic cups are placed in two rows of eight to twelve cups along the spine and are left attached for 5-20 minutes.

The second method, so-called wet cupping or bleeding cupping, is not currently as common in the Czech Republic as in the foreign context, where based on 550 studies it comprises around $58 \%$ of all methods (Cao et al. 2010). In the Czech Republic, this method rather refers to the historical context of medieval healing, when it had great popularity along with the method of bloodletting, which can be traced in the historical treatises from the $16^{\text {th }}$ century in the so-called bloodletting calendars (Zíbrt 1924). Currently, it can only be performed in doctors' surgeries in the Czech Republic, but they do not usually work with this method. In this variant, there is a small incision of the skin or just piercing the skin with a needle and after attachment a small amount of blood is sucked out. This is what makes wet cupping therapy the most widely used method in the global context, as it is believed that this pathway leads to the greatest elimination of the causative pathological substances and restoration of normal physiology as compared to dry cupping therapy, which depends on dilution and redistribution of the causative pathological substances to new sites (El Sayed, Mahmoud, Nebo et al. 2013). This is also the case in Ukraine among the majority population and Ukrainian emigrants settled in other parts of the world, such as Canada (Klymasz 1989, 1991).

Other methods of cupping therapy are not common in the Czech Republic; exceptionally, there is a combination of cups with magnets, electrostimulation and, above all, complementary massage during cupping therapy, when the therapist moves the cup on the body (most often the back) of the patient in places that require treatment (moving cupping). This is also related to the most frequently treated sites and the explanatory scheme of the effect of cups.

In the Czech Republic, it is possible to encounter a typical explanation of the use of cupping therapy in musculoskeletal problems of the movement apparatus, but also with the application of a wider field of action in the spirit of Paracelsus's motto - "Where nature created pain, harmful substances have accumulated there". The effect of the cups is manifested in addition to local loosening of stiff muscles 
and removal of pain also in the bloodstream, when the blood is cleared, the lymph flows, there is improved blood circulation and the removal of harmful substances from the body (Zentrich, Jonás 1990). From the perspective of Chinese medicine, the problems in the spine area are also related to the system of meridians, or energy paths and centres deposited on the vertebrae. These to some extent correlate with the transverse band segmentation in the back region called the Head Zones, also called reflex zones or segments that are related to the formation of skin districts with nerve supply originating from the spinal vertebrae (Beltrán Molano et al. 2014). Communication between reflex zones (segments) and internal organs is probably mediated by a reflex arc of the neural connection between the skin and the respective internal organ. In disorders and diseases of internal organs, painful point sections (manifested by hardness) form at some points of the transverse segmentation. The point sections are characteristic of individual organ systems. In this context, the success of the cups likely lies not only in improving the blood circulation and relieving pain at the sore place but also sending a healing impulse to the associated internal organ.

Cupping therapy is generally used for the therapy of a wide range of diseases, from the most frequently mentioned pain states (chronic muscle pain, generalized pain, infection pain, neuralgia pain), through respiratory disease (asthma, the common cold, cough), diseases of the skin (herpes zoster, acne, neurodermatitis, urticaria, psoriasis), to various problems of the type: lateral femoral cutaneous neuritis, mastitis, insomnia, hypertension, carpal tunnel syndrome, fatigue, facial paralysis and many other diagnoses and issues (Cao et al. 2010; Mehta, Dhapte 2015).

Cupping therapy and education in the practice of cupping is currently offered in the Czech Republic in places dedicated to promoting a healthy lifestyle, places dealing with problems of the movement apparatus and massage techniques. Guest personalities from abroad organizing paid courses are also available. Thus, there is a syncretic mixing of different species, methods and influences in cupping therapy on the territory of the Czech Republic and there is no uniform procedure or approach to the evaluation practice necessary to maintain good therapeutic practice. This is also a challenge for legislators and the creators of the rating standards to reflect on the introduction of study and practice for healthcare professionals and medical care professionals concerning the assessment of the effectiveness and safety of not only cupping therapy, but generally all CAM practices that are so lacking in the Czech Republic. The Ministry of Health in the Czech Republic currently offers a standardized state licensing exam only for health professionals like physicians, dentists, nurses, pharmacists and paramedical personnel (CAM Regulation 2013).

Perhaps that is precisely why many of my interviewed respondents, resettled from Ukraine, complained in their recollections about the fact that no one properly knows cupping therapy here in the Czech Republic, except for trained in- 
terns of Chinese medicine, who offer their services for high amounts of money though. However, as arises from the current market offerings and historical narratives of the respondents, there was much greater interest in cupping therapy in the $2^{\text {nd }}$ half of the $19^{\text {th }}$ century in the Czech Lands, probably due to the unavailability and inadequacy of official medical care and the then absolute absence of so-called evidence-based medicine, which blurred the differences between evidence-based medicine and placebo-effect-based medicine.

\section{Cupping Therapy within the Czech Community in Ukraine}

Treatment using cups found its trainees also among the Czech population, who settled Ukrainian villages in the $2^{\text {nd }}$ half of the $19^{\text {th }}$ century and remained in them until the end of WWII, to a lesser extent until the 1990s. The specificity of their legacy lies in the coding the method of cupping therapy from the time of their emigration from the Czech lands and thus preservation of an archaic method of using cups, which appeared in the $2^{\text {nd }}$ half of the $19^{\text {th }}$ century on the territory of the Czech lands (Bohemia and Moravia parts of the Austrian monarchy then). It thus offers us a historically interesting insight into the form of this CAM practice. Given that the Czech population showed a compact Czech settlement on the territory of Ukraine, we can derive from their recollections the degree of integration and diffusion of foreign elements (especially from the neighbourhood inhabited by Ukrainians and Poles), which was not high. Nevertheless, in the case of cupping therapy, there is a general similarity in implementation for all Slavic nations, which, fortunately, was preserved in the minds of its users due to the economic shortage of the time [similarly, the archaic form of cupping brought by Ukrainians to Canada for instance (Klymasz 1989; 1991), or the memories of the Czech respondent from Mala Zubovschina, Kiev region, who described the same archaic practice with her Czech grandmother, who learned it from 'someone from Ukraine' - further in the text - or cases from the Polish milieu (Moszynski 1967)]. Their knowledge correlates with records from older written archival materials written on the territory of Bohemia and Moravia parts of the then Austrian monarchy. This archaic form of cupping therapy thus perhaps/probably refers to the old form of this practice of the Slavic peoples as a whole.

From the memories of respondents of Czech origin living in Ukraine we come to the finding that they most used ceramic mugs or smaller glasses of rounded shape, which were first heated in sufficiently warm water before they were applied to the affected painful place, which was previously lubricated with an ointment or more usually pork lard. The oldest form of cupping therapy is considered to be that with the use of bread. On the place, where the cup was to be applied, a piece of bread or a piece of raw potato was put, in which 3 matches shortened in half were stuck [the magic effect of the number three referring to the holy trinity in the 
Christian tradition appearing also with the practices of the so-called blurring or diminishing 'mzí' or 'oubyti' - the treatment of malaise, fatigue, and the treatment of the so-called 'rose' (Pityriasis rosea) - a painful dermatological disease most often of bacterial origin. The number three and its multiples are significant magical but also Christian symbols accompanying the majority of healing rituals not only in the Czech lands then as a component of the medical methods and formulas but also in Ukraine (Phillips 2004), in Russia (Ryan 1999), and across the Euro-American space (Hand 1980)]. The matches were then lit and immediately covered by a cup. The cup was left to act for $c a 20$ minutes, then it was gently removed and the painful place was massaged. The cups were thus applied as needed, daily or every other day, until the feeling of relief. According to their recollections, back pain was mainly treated, but also pneumonia, when the cups were applied twice a day for several days. At the same time, one of the witnesses does not rule out taking over some elements from local residents, in this case most often Ukrainians, however, her mother brought her way of practicing from the then Austro-Hungarian village Josefín (woman, b. 1912, Olyka, district of Dubno, Volhynia region).

Another witness from the Volhynia region remembers the following method of conducting the so-called 'building' of cups. She remembers the use of glasses of about $1.5 \mathrm{dcl}$ with curved edges made of thin glass, which were carefully washed in warm water before use. Then her grandmother prepared denatured alcohol in a small bowl and a wood chip or stick, which she wrapped in cotton wool at the end, ignited the burner and lit the cotton wool soaked in the alcohol on the stick and then used it to suck the oxygen from the cup and stuck the cup on her skin. The witness adds:

I liked to watch this procedure. It was an art; it seemed simple but for those who tried it without practice, the cups usually did not suck or soon fell off (...) it was a good treatment for colds, fever, back pain. The cups were applied along the entire length of the back, but they were also applied when seated only on the upper back after some effort (...) (woman, b. 1933, Kupičov, district of Vladimir Volynsky, Volhynia region).

An interesting example was also provided by a respondent from Malá Zubovschina from the Kiev region, who remembered how cups were used by her grandmother, who came from Nechanice in the Hradec Králové District (the Bohemian part of the then Austrian monarchy). Mostly, they used them in the household in large quantities on their backs for pneumonia or back pain. Another procedure, influenced by influences from an ethnically different milieu, was then reportedly taught by 'someone from Ukraine, from some Ukrainian village', when she combined knowledge from her Bohemian homeland with new knowledge. This method is unique not only to the archaic use of matches embedded in the bottom of bread, but also to the placement of a single flask and an 'explanation' of its use and effect, referring to the sympathetic magic: 
A small circular glass was necessary for that, as a cup (when a person was larger, then a larger glass) and a piece of bread cut according to the shape of the glass. The person lay on their back, the bread was placed on the area of the stomach, matches were stuck in it, which fit it, they were lit and covered by the cup, which stuck to the skin. It was left until all the matches burnt out there was smoke in the cup. And the skin along with the bread and matches rose and the more the stomach hurt, the more the skin was pulled upwards into the cup. This was how the cup was built when the stomach ached. My grandmother always said she had to 'lift up' the stomach that the stomach was 'released' as hard as a man worked - and the cup had the task of lifting his stomach. I think it was done about two or three times. Only to small children didn't do it... After it ended, the bread and matches were removed and sometimes we buried that bread at home too. No animal was nor were we allowed to eat it. I think it was buried in the corner of the "shack" (cottage), where water was poured out (woman, b. 1963, Malá Zubovschina, Kiev region - her grandmother, b. 1909, Nováky - then Bohemia, later Malá Zubovschina, Kiev region).

This aforementioned method is unique not only for its execution but mainly for its reference to the magical character of the thought, which we find with other kinds of healing in the Kiev and Volhynia regions with the Czech community, such as blurring or diminishing 'mzí' or 'oubytí, treating pityriasis rosea, treating an earache, warding off curses (Beranská 2017, 2011, 2013, in a modified form with other elements in the Ukrainian community (Phillips 2004; Klymasz 1989; 1991), but on the general level it does not appear with the interpretative scheme of the use of cupping therapy. It is thus one of the oldest healing practices at all.

In all of the cases of cupping therapy captured in the memories of the Czech resettled from the Volhynia or Kiev regions, various forms of so-called dry cupping figure with the aid of a roll of grass or cotton wool wrapped on a stick soaked in alcohol, or an archaic form of the use of bread and sticking matches or the sticks or a candle along in the creation of the vacuum in the cup and its sucking onto the skin. The case of wet or bleeding cupping was recorded for comparison with a respondent from the southern part of Ukraine, specifically from the Odessa region, whose grandmother used razor blades to cut the skin under cups. She used a stick with cotton wool soaked in homemade alcohol to divert the oxygen from the cups and then applied the cups most often into the lower part of the spine. After removing the cups, there was a massage. She sometimes also performed a massage of the attached cups themselves. The testimony of the witnesses differ in many ways, concerning the number of cups used - from six to thirty, often under the slogan - the greater the pain, the more the cups (man, b. 1928, Buderáž, district of Dubno, Volhynia region), also the period of its action was changeable - 20 to 40 minutes (woman, b. 1936, Moštěnice, district of Ostroh, Volhynia region). Mostly women of older age worked the cups in their families, but they were also often an integral part of the medical bag of the local doctor, if there was any in the village. 


\section{Methods}

Data on practices related to folk medicine and complementary and alternative medicine (CAM) with the people who re-emigrated from Ukraine was collected in 2008-2019 on the territory of the Czech Republic within three waves of resettled Czechs from Ukraine. The data concerning folk medicine - predominantly phytotherapy, along with ritual elements of sympathetic magic and verbal spells, was summarized in a dissertation (Beranská 2017) and already published article (Beranská 2011; Beranská 2013). The information associated with defensive practices and treatment strategies with so-called Chernobyl Czechs (resettled in 1991-1993) was summarized in a text in 2016 (Beranská, Uherek, 2016; Uherek, Beranská 2015). The data concerning cupping therapy for this text was collected all over the territory of the Czech Republic, where ca 50 interviews were conducted.

The sample examined was compiled based on data obtained shortly after resettlement in the 1990s by the Ethnological Institute of the Czech Academy of Sciences, which has been studying, among other things, the adaptation and integration of these groups in the Czech milieu since the very beginning of statecontrolled migration (from the mid-1940s). The research sample was compiled in connection with previous research surveys and the method of acquiring new contacts from existing respondents, the so-called snowball sampling method, which, despite its shortcomings, is still suitable for specific groups of respondents (Adler, Clark 2010; Naderifar, Goli, Ghaljaie, 2017). Despite the considerable diversity of the locations of the arrivals, in terms of age it was a relatively homogenious group of respondents with members of mainly the older generations (average age of 60) and a gender imbalance (the respondents were predominantly women $-90 \%$, men took part in the interviews, but to a large extent did not remember the details of the treatment techniques). During the research survey, qualitative research techniques were used, especially structured interviews with subsequent evaluation using content analysis. Therefore, respondents' testimonies are combined in the text with references to the relevant literature.

\section{Conclusion}

This article presents the data on cupping therapy in the historical context of Czechs living in Ukraine outside the territory of their homeland from the $2^{\text {nd }}$ half of the $19^{\text {th }}$ century, who re-emigrated back to the territory of the Czech Republic in the $2^{\text {nd }}$ half of the $20^{\text {th }}$ century in light of contemporary complementary and alternative medicine in the Czech Republic. Thanks to the relative cultural isolation of the Czech community on the territory of the former USSR, archaic forms 
of healing methods imported from the territory of the then Austrian monarchy of the $2^{\text {nd }}$ half of the $19^{\text {th }}$ century were preserved, which after considering the surrounding ethnic influences on Ukrainian territory, can be used for the possibility of comparison with other studied groups across the states of Central and Eastern Europe in a similar time frame. The article also provides a look into the context of folk medicine and complementary and alternative medicine (CAM) in the Czech Republic, the situation of the position of Chinese medicine (CM) in the field of Czech medical care in the medium term and the historical context of cupping therapy on the territory of the Czech Republic, when it introduces the transformations in the methods of using individual forms - from the prevailingly widely used bleeding cupping therapy in the past to the rather sporadically used dry cupping therapy in the present. Due to the syncretism and blending of individual foreign influences, a typical method of cupping therapy performed in the Czech Republic cannot be described at present. Nor can its official description be provided due to its legislative enshrinement not existing in the area of the conduct of treatment interventions outside the area of so-called evidence-based medicine. That might be why, given the increased interest of the Czech population in CAM methods and practices, a more detailed description and research of this practice and its impact on health and state of a disease are needed. I hope that contemporary and historical data of this kind make an important contribution to the interest in this and other CAM practices on the territory of Central and Eastern Europe and will encourage efforts to acquire high-quality evidence to support the use of cupping therapy in various types of health problems.

\section{Bibliography}

Abele J.

2006 Baňkování - osvědčená metoda léčby, Hradec Králové.

Aboushanab T.S., AlSanad S.

2018 Cupping Therapy: An Overview from a Modern Medicine Perspective, "Journal of Acupuncture and Meridian Studies", nr 11, p. 83-87.

Adler E.S., Clark R.

2010 An Invitation to Social Research: How It's Done, Stanford, CT.

Beltrán Molano M.L. et al.

2014 Anatomo-functional Correlation between Head Zones and Acupuncture Channels and Points: A Comparative Analysis from the Perspective of Neural Therapy, "Evidence-Based Complementary and Alternative Medicine", nr 83, p. 63-92.

Beranská V.

2011 Komplementární (lidová) léčba u přesídlených krajanů z Ukrajiny a Kazachstánu, in: B. Iljuk (ed.), Identita migrantů z východní Evropy a jejich integrace $v$ českém prostředí, p. 61-75, Hradec Králové.

2013 Krajanská lidová léćba a ritualizované praktiky u Čechů z Ukrajiny a Kazachstánu preséidlených do České republiky, "Národopisná revue", nr 23, p. 264-271. 
2017 Lidové léčení v pamětech i žité prítomnosti presídlených krajanů z oblasti bývalého Sovětského svazu, dissertation, Praha (unpublished result).

Beranská V., Uherek Z.

2016 The Defensive Strategies of Czech and Ukrainian Residents in the Ukraine against the Effects of the Chernobyl Nuclear Accident, „Český lid/The Czech Ethnological Journal", nr 103 (1), p. 85-101.

CAM Regulation - Czech Republic

2013 General Summary about the Country's Legislation of CAM, http://cam-regulation.org/en/czech-republic (access: 26.11.2019).

Cao H. et al.

2010 Clinical Research Evidence of Cupping Therapy in China: A Systematic Literature Review, "BMC Complementary and Alternative Medicine", nr 10 (70), p. 1-10.

Cikrt T.

2019 Každý může být léčitelem s posvěcením státu. Podle chystaného zákona se stačí jen zaregistrovat. Zdravotnický deník.cz, https://www.zdravotnickydenik.cz/2019/01/ kazdy-muze-byt-lecitelem-posvecenim-statu-podle-chystaneho-zakona-se-staci-jen-zaregistrovat/ (access: 26.11.2019).

El Sayed S.M., Mahmoud H.S., Nebo M.M.H.

2013 Methods of Wet Cupping Therapy (Al-Hijamah): In Light of Modern Medicine and Prophetic Medicine, “Alternative \& Integrative Medicine”, nr 2 (3), p. 1-16.

Ember C.R., Ember M. (eds.)

2004 Encyklopedia of Medical Anthropology. Health and Illness in the World's Cultures . Volume I. Topics/Volume II. Cultures. New York.

Foster G. M., Anderson B. G.

1978 Medical Anthropology. New York.

Geest S.V.

2007 A Cultural Fascination with Medicine: Medical Anthropology in the Netherlands, in: F. Saillant and S. Genest (eds.), Medical Anthropology. Regional Perspectives and Shared Concerns, Malden, p. 162-182.

Halasová Š.

2006 Holistic Medicine Stands on Firm Ground in the Czech Republic, Czech Radio Praha, https://www.radio.cz/en/section/panorama/holistic-medicine-stands-on-firm-ground-in-the-czech-republic (access: 1.12.2019).

Hand W.D.

1980 Magical Medicine: The Folkloric Component of Medicine in the Folk Belief, Custom, and Ritual of the Peoples of Europe and America, Berkeley-Los Angeles.

Choceňský J.

1532 O krvi pouštění žilami i baňkami, w: Č. Zíbrt, Staročeská tělověda a zdravověda, p. 59-73, Praha.

iDNES

2018 Vzniká nový zákon o léčitelích. Stát je chce mít pod kontrolou, https://www.idnes.cz/ zpravy/domaci/lecitele-zakon-ministerstvo zdravotnictvi.A181106_437616_domaci_ zaz (access: 26.11.2019).

Kenety B.

2019 Traditional Chinese Medicine Centre in Hradec Králové Closing, https://www. radio.cz/en/section/news/traditional-chinese-medicine-centre-in-hradec-kralove-closing (access: 11.11.2019). 
Kleinman A.

1980 Patients and Healers in the Context of Culture. An Exploration of the Borderland between Anthropology, Medicine and Psychiatry, Berkeley.

Klymasz A. K.

1989 Ukrainian Folk Medicine in Canada, "Material Culture Review", nr 29, p. 99-101. Klymasz A. K.

1991 „Folk Medicine: A Ukrainian Canadian Experience“. Master of Arts thesis. Winnipeg: Department of Anthropology, University of Manitoba.

Knotek K. et al.

2012 Prevalence and Use of Herbal Products in the Czech Republic: Over-the-Counter Survey among Adult Pharmacies Clients, "Complementary Therapies in Medicine", nr 20, p. 199-206.

Krajané na Ukrajině

2014 Ministerstvo zahraničních věcí České republiky, https://www.mzv.cz/jnp/cz/encyklopedie_statu/evropa/ukrajina/krajane/-mzv-publish-cz-udalosti_a_media-fakta_a_ data_k_aktualitam-x2014_10_03_krajane_na_ukrajine.html (access: 1.12.2019).

Křížová E.

2001 Jak uživají čeští pacienti alternativní léčebné postupy a jak hodnotí jejich efekty? (Sociologický průzkum zkušeností s alternativní medicínou a postojů $k$ ní), "Praktický lékař”, nr 81, p. 32-38.

2013 Co je nekonvenční (komplementární a alternativní) medicína a čím se vyznačuje?, "Psychosom. Časopis pro psychosomatickou a psychoterapeutickou medicínu", nr 4, p. 234-243.

2018 Alternativní medicína - diskuse v kruhu, "Vesmír", nr 97 (640).

Leff C. Skalnik

2018 The Czech and Slovak Republics: Nation versus State, New York.

Mehta P., Dhapte V.

2015 Cupping Therapy: A Prudent Remedy for a Plethora of Medical Ailments, "Journal of Traditional and Complementary Medicine", nr 5, p. 127-134.

Moszyński K.

1967 Medycyna, in: J. Burszta (ed.), Kultura ludowa Słowian, vol. 2: Kultura duchowa, p. 175-232, Warszawa.

Naderifar M., Goli H., Ghaljaie F.

2017 Snowball Sampling: A Purposeful Method of Sampling in Qualitative Research, "Strides in Development of Medical Education", nr 14, e67670.

Pavlík J.

1897 Slovník domácího lékařství a zdravotnictví, Praha.

Phillips D.S.

2004 Waxing Like the Moon: Women Folk Healers in Rural Western Ukraine, "Folklorica", nr IX, p. 13-45.

Piotrowski-Manz H.

2007 Die Kunst des Schröpfens. Grundlagen, Durchführung, Naturheilkundliche Therapiekonzepte, Stuttgart.

Pokladnikova J., Selke-Krulichova I.

2016 Prevalence of Complementary and Alternative Medicine Use in the General Population in the Czech Republic, "Forsch Komplementmed" nr 23, p. 22-28. 
2018 Prevalence of Complementary and Alternative Medicine Use in the General Population in the Czech Republic: A Follow-up Study, "Complementary Medicine Research" nr 25, p. 159-166.

Qureshi N.A. et al.

2017 History of Cupping (Hijama): A Narrative Review of Literature, "Journal of Integrative Medicine", nr 15, p. 172-181.

Ryan W.F.

1999 The Bathhouse at Midnight: An Historical Survey of Magic and Divination in Russia, Pennsylvania.

SČVP - Základní informace o Češích na Volyni, http://www.scvp.eu/downloads/Zakladni_informace_o_Cesich_na_Volyni.pdf (access: 1.12.2019).

Stöckelová T., Klepal J.

2018 Evidence-based Alternative, „Slanted Eyes” and Electric Circuits: Doing Chinese Medicine in the Post-socialist Czech Republic, in: C. Brosnan, P. Vuolanto, J.A. Danell (eds), Complementary and Alternative Medicine: Health, Technology and Society, p. 33-58, Cham.

Škoda E.

2002 Cesty české alternativní léčby. Metody a osobnosti, Praha.

Taneček D.

2019 Tradiční čínská medicína v Hradci Králové končí. Ordinaci zavře v únoru. ČT 24, https://ct24.ceskatelevize.cz/regiony/2730872-tradicni-cinska-medicina-v-hradci-kralove-konci-ordinace-zavre-na-konci-unora (access: 26.11.2019).

Uherek Z.

2011 Češi v Bosně a Hercegovině, Praha.

Uherek Z., Beranská V.

2015 Pavlivka Iodine Spring Water: Transnational Entrepreneurship in Post-transition Contexts, in: H. Červinková, M. Buchowski, Z. Uherek (eds), Rethinking Ethnography in Central Europe, p. 75-88, New York.

Valášková N., Uherek Z., Brouček S.

1997 Aliens or One's Own People: Czech Immigrants from the Ukraine in the Czech Republic, Prague.

Vaněk M., Mücke P.

2016 Velvet Revolutions: An Oral History of Czech Society (Oxford Oral History Series), Oxford.

Zentrich J.A., Jonáš J.

1990 Věčně zelené naděje, Ústí nad Labem.

Zíbrt Č.

1924 Staročeská tělověda a zdravověda, Praha. 